\title{
PENGARUH PERILAKU DAN KINERJA PEGAWAI TERHADAP KUALITAS PELAYANAN PUBLIK PADA DINAS KEPENDUDUKAN DAN CATATAN SIPIL KABUPATEN DAN KOTA DI PROVINSI KALIMANTAN SELATAN
}

\author{
Murdiansyah Herman \\ Universitas Islam Kalimantan Muhammad Arsyad Al Banjari \\ Email: murdiansyahuniska@gmail.com
}

\begin{abstract}
Analyze the influence of behavior on the quality of public services, behavior on performance, and performance on the quality of public services at the Population and Civil Registry Service in the Province of South Kalimantan. This research uses quantitative methods which can be interpreted as research methods based on positivist philosophy. The design of this study was observational with a cross sectional approach. The sample of this study was 325 people and spread in 13 cities and districts in the Province of South Kalimantan. The results of this study are that employee behavior has a significantly positive effect on employee performance. Employee behavior significantly influences the Quality of Public Services. Employee performance does not significantly influence the Quality of Public Services.
\end{abstract}

Keywords: behavior, performance, quality of public services

\section{PENDAHULUAN}

Salah satu aspek mendasar pemberian otonomi kepada daerah adalah keleluasaan pemerintah daerah untuk menyelenggarakan pemerintahan sendiri atas dasar prakarsa, kreativitas, dan peran serta aktif masyarakat dalam rangka mengembangkan dan memajukan daerahnya. Selain itu, adanya pemberian kewenangan untuk mengatur dan menyelenggarakan urusan pemerintahan berdasar skala pelayanan umum apakah lebih efektip diselenggarakan oleh daerah ataukah oleh pusat.

Terselenggaranya pemerintah yang bersih, baik dan berwibawa (clean and good governance) telah lama menjadi cita-cita dan harapan setiap bangsa termasuk bangsa Indonesia. Pemerintahan yang bersih baik dan berwibawa ditandai dengan adanya akuntabilitas (accountability), transparansi (transparency), keterbukaan (openness), dan kerangka hukum (rule of law). Akuntabilitas lebih diarahkan pada kewajiban bagi aparatur pemerintah untuk bertindak selaku penanggung gugat atas segala tindakan dan kebijakan yang ditetapkannya. Transparansi lebih mengarah pada kejelasan mekanisme formulasi dan implementasi kebijakan, program dan proyek yang dibuat dan dilaksanakan oleh pemerintah.

Penerapan kebijakan otonomi daerah di Indonesia menimbulkan harapan besar bagi masyarakat, terutama dalam hal peningkatan pelayanan publik. Tuntutan masyarakat telah berkembang dengan menginginkan adanya birokrasi dalam organisasi pemerintahan yang profesional khususnya dalam pelaksanaan pelayanan publik yang berkualitas.

Pada otonomi daerah, urusan manajemen pelayanan menjadi kewenangan pemerintah daerah sehingga akan mendekatkan jarak antara pemberi pelayanan dan yang dilayani. Pemerintah daerah dianggap dapat lebih memahami keinginan penduduk lokal sehingga pengambilan keputusan dalam penyediaan pelayanan lebih responsif terhadap permintaan masyarakat (Utomo, 2012).

Berhasil tidaknya sebuah pelayanan birokrasi pemerintah kepada masyarakat sangat ditentukan oleh perilaku birokrat. Birokrat yang lebih dikenal dengan Aparatur Sipil Negara (ASN) harus mampu menyelenggarakan 
pelayanan publik bagi masyarakat. Aparatur Sipil Negara sebagai bagian dari reformasi birokrasi, berfungsi dalam pelayanan publik dan bertugas melaksanakan kebijakan publik serta memberikan pelayanan publik secara profesional dan berkualitas untuk masyarakat.

Sherwood dalam Supriyono (2008) menyatakan profesionalisme pemerintah sedang mengalami pemunduran, saat ini lebih banyak pejabat politik dalam birokrasi, dan lingkungan kerja belum mendukung atau belum dapat dipercaya. Tetapi pejabat pemerintah mempunyai peran penting untuk memulihkan lingkungan kerja agar sesuai dengan standar profesionalisme. Profesional yang dimaksud adalah merupakan keandalan dan keahlian dalam pelaksanaan tugas sehingga terlaksana dengan mutu tinggi, waktu yang tepat, cermat dan dengan prosedur yang mudah dipahami dan diikuti oleh pelanggan (Siagian, 2013). Seorang pegawai yang memiliki sikap profesional akan terus menekuni pekerjaanya dengan keahlian yang dimilikinya dengan tujuan untuk memberikan pelayanan kepada masyarakat dengan penuh disiplin dalam menjalankan tugas pekerjaannya.

Berdasarkan PP No. 53 Tahun 2010 bahwa pegawai negeri sipil dituntut untuk memberikan pelayanan sebaik-baiknya kepada masyarakat serta disiplin, hal ini menandakan bahwa seorang pegawai harus memiliki kinerja yang baik dalam bekerja. Sinambela (2016) mengemukakan bahwa kinerja pegawai sebagai kemampuan pegawai dalam melakukan suatu keahlian tertentu. Kinerja pegawai sangatlah perlu, sebab dengan kinerja ini akan diketahui seberapa jauh kemampuan mereka dalam melaksanakan tugas yang diembankan kepadanya, khususnya terhadap pelayanan kepada masyarakat.

Dengan demikian bidang pelayanan publik masih perlu mendapat perhatian dan pembenahan secara sungguh-sunguh dalam berbagai sektor yang menjadi pendukung terselenggaranya pelayanan publik yang efektif sehingga dapat menjawab tantangan yang ada yaitu memberikan pelayanan yang professional guna memenuhi tuntutan masyarakat.

Menurut UU No 25 tahun 2009, Bab 1 pasal 1 ayat 1 tentang pelayanan publik, mendefinisikan bahwa pelayanan publik adalah kegiatan atau rangkaian kegiatan dalam rangka pemenuhan kebutuhan pelayanan sesuai dengan peraturan perundang-undangan bagi setiap warga negara dan penduduk atas barang, jasa, dan pelayanan administratif yang disediakan oleh penyelenggara pelayanan publik.

Pemberian pelayanan publik oleh aparatur pemerintah kepada masyarakat merupakan implikasi dari fungsi aparat negara sebagai pelayan masyarakat sehingga kedudukan aparatur pemerintah dalam pelayanan umum (publik service) sangat strategis karena akan menentukan sejauhmana pemerintah mampu memberikan pelayanan yang sebaik-baiknya bagi masyarakat dan sejauhmana negara telah menjalankan perannya dengan baik sesuai dengan tujuannya. Pelayanan publik merupakan kegiatan yang dilakukan oleh seorang atau sekelompok orang atau instansi tertentu dengan tujuan memberikan bantuan pelayanan yang akan mempermudah masyarakat untuk mencapai tujuan tertentu.

Dalam konteks pelayanan publik yang bergerak menuju yang lebih baik, telah terjadi pergeseran paradigma pelayanan publik dari paradigma tradisional ke paradigma demokrasi, yang dikenal dengan 3 model yakni model administrasi publik tradisional (Old Public Administration, OPA) yang kemudian bergeser ke model manajemen publik baru (New Public Management, NPM), dan akhirnya menjadi model pelayanan publik baru (New Public Service, NPS), sebagaimana digambarkan oleh menurut Denhardt dan Denhard (2000).

Ketiga paradigma tersebut menunjukkan perkembangan makna pada perspektif bahwa pelayanan publik hadir untuk kepentingan siapa, dan bagaimana paradigma ini memposisikan masyarakat. Selaras dengan azas demokrasi yang menjiwai pelayanan publik, maka paradigma yang dianggap ideal adalah New Public Service (NPS), yaitu pelayanan publik yang responsif terhadap berbagai kepentingan publik, yang selaras dengan konsep pelayanan publik demokratis atau yang dalam konsepsi Habermas, pelayanan publik deliberatif (dikonsultasikan kepada publik). Konsepsi NPS ini memberikan ruang bagi pemberian pelayanan yang sesuai dengan kepentingan masyarakat 
(citizens) sebagai penerima layanan, tidak hanya sebatas pada pelanggan (customers).

Kualitas pelayanan publik dapat diukur dari aspek proses dan output pelayanan. Karena tujuan utama pelayanan publik adalah memenuhi kebutuhan penggunanya, maka penyedia layanan harus mampu mengidentifikasi kebutuhan pengguna layanannya untuk memastikan pelayanannya tepat guna dan tepat sasaran.

Berdasarkan data laporan masyarakat ke Ombudsman RI Perwakilan Kalimantan Selatan, kasus mal administrasi di Kal-Sel masih sering terjadi di kota/kabupaten. Kasus tersebut dikelompok Ombudsman dalam 9 kelompok yaitu, penundaan berlarut, tidak memberikan pelayanan, tidak patut, penyalahgunaan wewenang, penyimpangan prosedur, diskriminasi, permintaan uang, barang \& jasa, berpihak, dan tidak kompeten. Pada tahun 2013 kasus mal administrasi yang dilaporkan masyarakat ke Ombudsman RI Perwakilan Kalimantan Selatan, untuk klasifikasi terlapor kota/kabupaten sebanyak 58 kasus $(38,7 \%)$ dari semua lembaga terlapor, kasus tersebut tersebar di 12 kota/kabupaten, hanya 1 kabupaten yang tidak dilaporkan. Tahun 2014 kasus mal administrasi di kota/kabupaten meningkat yaitu 62 kasus $(46,6 \%)$, kasus tersebut tersebar disemua kota/kabupaten di Kal-Sel. Tahun 2015 kasus mal administrasi juga meningkat, kota/kabupaten yang dilaporkan 77 kasus $(66,4 \%)$, pada tahun ini juga diketahui bahwa laporan masyarakat tersebut berasal dari semua kota/kabupaten di Kalimantan Selatan.

Kasus mal administrasi yang terjadi di kota dan kabupaten di Kalimantan Selatan pada tahun 2013 paling banyak terjadi pada kasus penundaan berlarut yaitu 30,6/\% dan kasus tidak memberikan pelayanan $26 \%$ dari 150 kasus mal administrasi yang terjadi. Tahun 2014 kasus tertinggi pada tidak memberikan pelayanan yaitu $38,16 \%$ dan penundaan berlarut 20,6\% dari 131 kasus mal administrasi. Sedangkan pada tahun 2015 kasus mal administrasi pada jenis kasus tidak memberikan pelayanan yaitu $36,52 \%$ dan kasus penundaan berlarut 27,1\% dari 115 kasus yang terjadi di Kalimantan Selatan.

Berdasarkan hal tersebut, maka perlu dilakukan penelitian untuk mengetahui bagaimana pelayanan publik yang diberikan oleh birokrasi pemerintah di Provinsi Kalimantan Selatan, dimana provinsi tersebut memiliki 2 kota dan 11 kabupaten. Salah satu pelayanan publik yang paling sering dibutuhkan masyarakat adalah pelayanan administrasi kependudukan seperti pembuatan Kartu Keluarga (KK), Kartu Tanda Penduduk (KTP), Akta Kelahiran dan Akta Kenal Lahir, Catatan Sipil Perkawinan, Surat Keterangan Mutasi Kependudukan, dan lain-lain. Oleh karena itu Dinas Kependudukan dan Catatan Sipil (Disdukcapil) adalah instansi yang tepat sebagai objek penelitian untuk mengetahui pelayanan publik yang diberikan kepada masyarakat.

Dari uraian di atas peneliti ingin mengetahui bagaimana perilaku pegawai dan kinerja dalam memberikan pelayanan publik di Dinas Kependudukan dan Catatan Sipil di Provinsi Kalimantan Selatan.

\section{TINJAUAN PUSTAKA}

\section{Dimensi Perilaku Pegawai}

Untuk menjelaskan perilaku pegawai tidak bisa terlepas dari komponen yang mendasari perilaku organisasi yakni adanya dorongan jiwa yang mempengaruhi pelaku organisasi, (orang yang memimpin atau yang memberikan. pelayanan) maupun. perilaku yang memang telah menjadi standar baku suatu organisasi. Komponen yang mendasari perilaku organisasi tersebut selalu terkait dengan aktifitas dan orang orang yang mempunyai kepentingan, pengharapan, sehingga oleh Hicks \& Gullet (2006) disebut bahwa "organisasi formal adalah bagai kendaraan bagi kepentingan orang banyak dalam. mencapai, tujuannya". Kemudian ditegaskan juga oleh Hicks \& Gullet (2006) bahwa "organisasi yang formal bergerak dengan suatu target".

Perilaku birokrasi sering juga disebut dengan perilaku pegawai dalam sebuah organisasi. Thoha (2012) mengemukakan bahwa pengertian perilaku adalah perilaku merupakan suatu fungsi dari interaksi antara seseorang individu dengan lingkungan. Ini formula psikologi dan mempunyai kandungan pengertian bahwa perilaku seseorang itu tidak hanya ditentukan sampai seberapa jauh interaksi antara 
dirinya dengan lingkungannya. Penjelasan definisi di atas dapat diartikan bahwa seseorang individu dengan lingkungannya menentukan perilaku keduanya secara langsung. Individu dengan organisasi tidak jauh berbeda dengan pengertian ungkapan tersebut. Keduanya mempunyai sifat-sifat khusus atau karakteristik tersendiri dan jika kedua karakterisitik ini berinteraksi maka akan menimbulkan perilaku individu dalam organisasi.

Hersey (2006) berpendapat perilaku pada dasarnya berorientasi pada tujuan. Artinya, perilaku orang pada umumnya dimotivasi oleh keinginan untuk meraih tujuan-tujuan tertentu, tetapi tujuan tersebut tidak selamanya diketahui secara sadar oleh individu yang bersangkutan. Dorongan yang memotivasi pola perilaku individu yang nyata dalam kadar tertentu berada pada alam sadar mereka. Menurut Ndraha (2014) perilaku adalah operasionalisasi dan aktualisasi sikap seseorang atau suatu kelompok dalam atau terhadap suatu (situasi dan kondisi) lingkungan (masyarakat, alam, teknologi, atau, organisasi), sementara sikap adalah operasionalisasi dan aktualisasi pendirian.

Sedangkan Davis (2008) berpendapat bahwa perilaku organisasi adalah telaah dan penerapan tentang bagaimana orang-orang bertindak di dalam organisasi. Perilaku organisasi adalah sarana manusia bagi keuntungan manusia. Perilaku organisasi dapat diterapkan secara luas dalam perilaku orangorang disemua jenis organisasi, seperti bisnis, pemerintahan, kemasyarakatan, sekolah dan organisai jasa lainnya. Apapun organisasi itu, ada kebutuhan untuk memenuhi perilaku manusia, karenanya perilaku manusia dalam organisasi agaknya tidak dapat diduga karena timbul dari kebutuhan dan sistem nilai yang terkandung dalam diri manusia.

Ada lima parameter yang dapat digunakan untuk mengukur/melihat perilaku birokrasi penyelenggaraan pelayanan publik (Robbins, 2006), yaitu :

1. Orientasi pelayanan, idealnya birokrasi yang mempunyai acuan utama, kebutuhan dan kepentingan masyarakat pengguna jasa dalam memberikan pelayanan, selalu berorientasi pada kepuasan pengguna jasa dan bukan kepuasan atasan / pimpinan bahkan kepuasan pribadi birokrasi.

2. Tindakan aparat dalam memberikan pelayanan. Tindakan yang mengacu pada kebutuhan dan kepentingan masyarakat pengguna jasa adalah tindakan yang membantu pengguna jasa dalam proses pelayanan.

3. Penggunaan sumber daya yang dimiliki birokrasi. Pemanfaatan segala sumberdaya yang dimiliki yang berupa sarana maupun prasarana.

4. Prioritas birokrasi dalam memberikan pelayanan, apakah kepada pemenuhan kepentingan masyarakat pengguna jasa atau kepada kepentingan yang lain (pimpinan, pribadi, dan lain-lain).

5. Solusi pelayanan, untuk mengukur solusi pelayanan yang diberikan aparat birokrasi parameternya adalah tindakan yang dilakukan aparat birokrasi ketika terdapat pengguna jasa yang mengalami kesulitan dalam pelayanan. Birokrasi yang akuntabel terhadap jasa adalah birokrasi yang mampu memberikan solusi pelayanan yang tidak mengecewakan atau tidak mempersulit pengguna jasa.

\section{Pelayanan Publik}

Pelayanan merupakan terjemahan dari istilah service dalam bahasa Inggris yang menurut Kotler yang dikutip Tjiptono, yaitu setiap tindakan atau perbuatan yang dapat ditawarkan oleh satu pihak ke pihak yang lain, yang pada dasarnya bersifat intangible (tidak berwujud fisik) dan tidak menghasilkan kepemilikan sesuatu (Tjiptono, 2014).

Sedangkan pelayanan publik menurut Alamsyah (2011) bahwa adalah setiap aktivitas pelayanan yang dilakukan pemerintah, individu, organisasi, dan yang lainnya dalam rangka merespon tuntutan individu, kelompok, organisasi, dan yang lainnya yang berhubungan dengan kepentingan keseluruhan populasi penduduk. Ratminto (2007) berpendapat bahwa pelayanan publik atau pelayanan umum dapat didefinisikan sebagai segala bentuk jasa 
pelayanan, baik dalam bentuk barang publik maupun jasa publik yang pada prinsipnya menjadi tanggung jawab dan dilaksanakan oleh Instansi pemerintah di pusat, di daerah, dan di lingkungan Badan Usaha Milik Negara atau Badan Usaha Milik Daerah, dalam rangka upaya pemenuhan kebutuhan masyarakat maupun dalam rangka pelaksanaan ketentuan peraturan perundang-undangan. Sedangkan Sadu Wasistiano (2001) mendefinisikan pelayanan umum atau pelayanan publik menurut adalah pemberian jasa baik oleh pemerintah, pihak swasta atas nama pemerintah ataupun pihak swasta kepada masyarakat, dengan atau tampa pembayaran guna memenuhi kebutuhan dan atau kepentingan masyarakat.

Untuk dapat menilai sejauh mana mutu pelayanan publik yang diberikan oleh aparatur pemerintah, perlu ada kriteria yang menunjukkan apakah suatu pelayanan publik yang diberikan dapat dikatakan baik atau buruk. Zeithaml (2009) mengemukakan tolok ukur kualitas pelayanan publik dapat dilihat dari sepuluh dimensi antara lain meliputi:

a. Tangible, terdiri atas fasilitas fisik, peralatan, personil, dan komunikasi.

b. Reliable, terdiri dari kemampuan unit pelayanan dalam menciptakan pelayanan yang dijanjikan dengan tepat.

c. Responsiveness, kemauan untuk membantu konsumen bertanggung jawab terhadap mutu layanan yang diberikan.

d. Competence, tuntutan yang dimilikinya, pengetahuan dan keterampilan yang baik oleh aparatur dalam memberikan layanan.

e. Courtesey, sikap atau perilaku ramah, bersahabat, tanggap terhadap keinginan konsumen serta mau melakukan kontak atau hubungan pribadi.

f. Credibility, sikap jujur dalam setiap upaya untuk menarik kepercayaan masyarakat.

g. Security, jasa pelayanan yang diberikan harus dijamin bebas dari berbagai bahaya dan resiko.

h. Access, terdapat kemudahan untuk mengadakan kontak dan pendekatan. i. Communication, kemauan pemberi layanan untuk mendengarkan suara, keinginan atau aspirasi pelanggan, sekaligus kesediaan untuk selalu menyampaikan informasi baru kepada masyarakat.

j. Understanding the customer, melakukan segala usaha untuk mengetahui kebutuhan pelanggan.

\section{Kinerja Pegawai}

Secara etimologi, kinerja berasal dari kata prestasi kerja (performance). Sebagaimana dikemukakan oleh Mangkunegara (2007) dalam Widodo (2015), bahwa istilah kinerja dari kata job performance atau actual performance (prestasi kerja atau prestasi sesungguhnya yang dicapai oleh seseorang) yaitu hasil kerja secara kualitas dan kuantitas yang dicapai oleh seseorang pegawai dalam melaksanakan tugasnya sesuai dengan tanggung jawab yang diberikan padanya. Sedangkan Sinambela (2016), mengemukakan pendapat lain bahwa kinerja merupakan pelaksanaan suatu pekerjaan dan penyempurnaan pekerjaan tersebut sesuai dengan tanggung jawabnya sehingga mencapai hasil sesuai dengan yang diharapkan.

Menurut Fahmi (2016), kinerja adalah hasil yang diperoleh oleh suatu organisasi tersebut bersifat profiet oriented dan non oriented yang dihasilkan selama satu periode waktu. Secara lebih tegas Amstrong dan Baron dalam Fahmi (2016), mengatakan kinerja merupakan hasil pekerjaan yang mempunyai hubungan kuat dengan tujuan strategis organisasi, kepuasan konsumen dan memberikan kontribusi ekonomi. Sedangkan Prawirosentono dalam Sinambela (2016), mengemukakan bahwa kinerja merupakan hasil yang dapat dicapai oleh seseorang atau sekelompok orang dalam suatu organisasi, sesuai dengan wewenang dan tanggung jawab masing-masing, dalam rangka upaya mencapai tujuan organisasi bersangkutan secara legal, tidak melanggar hukum dan sesuai dengan moral dan etika.

Djamaludin (2008) kinerja (performance) adalah kadar keberhasilan pegawai baik secara individu maupun bersama-sama dalam kelompok dan organisasi menjalankan kegiatan- 
kegiatan dengan sifat-sifat tertentu dalam menciptakan produk dan jasa-jasa untuk mencapai tujuan organisasi. Sedangkan Sukmalana (2007) memberikan pengertian kinerja merupakan sebagai sesuatu yang dikerjakan dan dihasilkan dalam bentuk produk maupun jasa dalam periode tertentu dan ukuran tertentu oleh seseorang atau sekelompok orang yang didasarkan pada kecakapan, kemampuan, pengetahuan maupun pengalamannya.

Rivai dan Basri (Sinambela (2016), mengatakan bahwa kinerja adalah hasil atau tingkat keberhasilan seseorang secara keseluruhan selama periode tertentu dalam melaksanakan tugas dibandingkan dengan berbagai kemungkinan, seperti standar hasil kerja, target atau sasaran atau kriteria yang telah ditentukan terlebih dahulu telah disepakati bersama. Sedangkan Nawawi (Widodo, 2015), menyatakan pendapat lain bahwa, kinerja adalah hasil pelaksanaan suatu pekerjaan, baik bersifat fisik/material maupun non fisik/non material. Dari beberapa pendapat para pakar tersebut, maka dapat disimpulkan bahwa yang dimakasud dengan kinerja adalah hasil kerja atas suatu pekerjaan selama periode tertentu yang dihasilkan dari perilaku seorang atau sekelompok pegawai secara kualitas dan kuantitas sesuai dengan wewenang dan tanggung jawab yang diberikan kepadanya di dalam suatu organisasi.

Lenvine dalam Dwiyanto (2009) mengemukakan tiga konsep untuk mengukur kinerja organisasi publik/organisasi non bisnis, yaitu:

1. Responsivitas (responsivennes) yaitu kemampuan organisasi untuk mengenali kebutuhan masyarakat, menyusun agenda dan prioritas pelayanan dan mengembangkan program-pro-gram pelayanan publik sesuai dengan kebutuhan dan aspirasi masyarakat. Semakin banyak kebutuhan dan keinginan masyarakat yang diprogramkan dan dijalankan oleh organisasi publik maka kinerja organisasi publik semakin baik.

2. Responsibilitas (responsibility), menjelaskan apakah pelaksanaan kegiatan organisasi publik itu dilakukan sesuai dengan prinsipprinsip administrasi yang benar atau sesuai dengan kebijaksanaankebijaksanaan organisasi. Semakin kegiatan organisasi publik itu dilaksanakan sesuai dengan prinsipprisnip administrasi, peraturan dan kebijaksanaan organisasi maka kinerjanya semakin baik.

3. Akuntabilitas (accountability), menunjuk pada seberapa besar kebijakan dan kegiatan organisasi tunduk pada para pejabat politik yang dipilih oleh rakyat (elected officials). Dalam konteks ini kinerja organisasi publik dinilai baik apa-bila sebagian besar kegiatannya didasarkan pada upaya-upaya untuk memenuhi harapan dan keinginan para wakil rakyat.

\section{METODE PENELITIAN}

Penelitian ini menggunakan metode kuantitatif yang dapat diartikan sebagai metode penelitian yang berladaskan filsafat positivism, digunakan untuk meneliti pada populasi atau sampel tertentu, pengumpulan data menggunakan instrument penelitian, analisis data bersifat kuantitatif, dengan tujuan untuk menguji hipotesis yang telah ditetapkan.

Rancangan penelitian ini berbentuk observasional dimana peneliti hanya melakukan observasi, tanpa memberikan intervensi pada variabel yang akan diteliti. Jenis yang digunakan untuk observasional adalah pendekatan cross sectional yaitu cara pengambilan data variabel bebas dan variabel tergantung dilakukan sekali waktu pada saat yang bersamaan.

Sampel penelitian ini ialah pegawai Dinas Kependudukan dan Catatan Sipil di Provinsi Kalimantan Selatan yang berjumlah 325 orang dan tersebar di 13 kota dan kabupaten.

Penelitian ini bertujuan menguji dan menganalisis hubungan kausal antara variabel eksogen dan endogen, sekaligus memeriksa validitas dan reliabilitas instrumen penelitian secara keseluruhan. Oleh karena itu digunakan teknik analisis Partial Least Square (PLS) dengan menggunakan software SmartPLS. 


\section{HASIL DAN PEMBAHASAN}

\section{Perilaku Pegawai}

Persepsi pegawai di Dinas Kependudukan dan Catatan Sipil Kabupaten/Kota di Provinsi Kalimantan Selatan terhadap variabel perilaku pegawai (X1), untuk indikator pelayanan yang diberikan aparat birokrasi yang berorientasi kepada kebutuhan dan kepentingan masyarakat pengguna jasa layanan $60,2 \%$ pegawai menyatakan setuju dengan hal tersebut, indikator tindakan yang dilakukan aparat birokrasi mengacu pada kebutuhan dan kepentingan masyarakat pengguna jasa dalam proses pelayanan sebagian besar pegawai $(79,81 \%)$ menyatakan setuju pernyataan tersebut. Mengenai indikator pelayanan yang diberikan aparat birokrasi yang memanfaatkan segala sumber daya yang dimiliki berupa sarana dan prasarana guna memenuhi kebutuhan dan kepentingan masyarakat pengguna jasa layanan sebagian besar $(66,3 \%)$ menyatakan setuju tentang hal tersebut.

Indikator pelayanan yang diberikan aparat birokrasi yang memprioritaskan kepada kebutuhan dan kepentingan masyarakat pengguna jasa dalam proses pelayanan, baru kemudian melaksanakan kepentingan lain seperti ; kepentingan pimpinan, kepentingan pribadi, dan lain-lain $55,1 \%$ pegawai menyatakan setuju. Indikator lainnya tentang pelayanan yang diberikan aparat birokrasi yang akuntabel dan mampu memberikan solusi pelayanan yang tidak mengecewakan guna memenuhi kebutuhan dan kepentingan masyarakat pengguna jasa dalam proses pelayanan $71,4 \%$ pegawai menyatakan setuju tentang hal tersebut.

Berdasarkan kelima indikator variabel perilaku pegawai, nilai mean terbesar ialah pada indikator erorientasi pada kebutuhan dan kepentingan masyarakat (X1.1), hal ini tercermin pada hasil layanan yang diberikan selalu sesuai dengan yang dubutuhkan oleh masyarakat di Provinsi Kalimantan Selatan. Orientasi ini mendukung perlunya mendapat penilaian yang baik dari para pengguna jasa layanan dan berusaha mempertahankannya oleh para pimpinan Dinas Kependudukan dan Catatan Sipil, dipercayanya sumberdaya sarana dan prasarana yang dimiliki guna mendorong peningkatan kualitas layanan oleh para pimpinan Dinas Kependudukkan dan Catatan sipil, yang kesemuanya itu mendorong terbentuknya Perilaku Pegawai yang baik. Indikator variabel perilaku pegawai dengan nilai mean terkecil ialah mengacu pada kebutuhan dan kepentingan masyarakat (X1.2).

Secara umum perilaku pegawai di dinas tersebut termasuk dalam kategori baik yaitu $66,3 \%$ dari total responden termasuk dalam kategori tersebut, sedangkan yang termasuk perilaku kerja kurang baik 33,7\%. Dengan demikian perilaku pegawai Dinas Kependudukan dan catatan Sipil Provinsi Kalimantan Selatan ini harus dapat ditingkatkan lagi, baik pada tingkatan pimpinan maupun para pegawainya. Dengan upaya-upaya dukungan di atas, maka perilaku pegawai yang dilakukan oleh pimpinan atau para pegawai Dinas Kependudukan dan Catatan Sipil di Provinsi Kalimantan Selatan dapat lebih ditingkatkan.

\section{Kinerja Pegawai}

Persepsi pegawai di Dinas Kependudukan dan Catatan Sipil Kabupaten/Kota di Provinsi Kalimantan Selatan terhadap variabel kinerja adalah sebagai berikut: untuk indikator pertama, responsivitas dari organisasi publik mampu mengenali kebutuhan masyarakat, menyusun agenda dan prioritas pelayanan serta mengembangkan program-program pelayanan publik sesuai dengan kebutuhan dan aspirasi masyarakat sebagian besar pegawai $(67,3 \%)$ menyatakan setuju tentang hal itu. Indikator kedua yaitu responsibilitas dari kegiatan organisasi publik yang wajib dilaksanakan sesuai dengan prinsip-prinsip administrasi, peraturan dan kebijaksanaan orgnisasi sebagian besar pegawai $(62,2 \%)$ menyatakan setuju. Sedangkan indikator, yang mentatakan akuntabilitas dari kegiatan organisasi publik berdasarkan pada upaya-upaya memenuhi harapan, saran, arahan, dan pandanganpandangan dari pihak legislatif dan sebaliknya pihak legislatif menghormati dan meninjau 
ulang dari saran, arahan dn pandngan-pandangan dari pihak legislatif $60,2 \%$ pegawai menyatakan setuju.

Indikator variabel kinerja pegawai dengan nilai mean terbesar ialah variabel responsibilitas, hal ini tercermin pada kegiatan kemampuan mengenali kebutuhan masyarakat, menyusun agenda dan prioritas pelayanan serta mengembangkan program pelayanan publik sesuai dengan kebutuhan dan aspirasi masyarakat pada kabupaten dan kota di Provinsi Kalimantan Selatan, yang kesemuanya itu mendorong kinerja organisasi publik menjadi sangat baik. Sedangkan indikator variabel kinerja pegawai dengan nilai mean terkecil ialah resposivitas, yakni kegiatan organisasi publik yang sebagian besar berdasarkan upaya-upaya memenuhi harapan. Dengan demikian kemampuan responsivitas dari para aparat birokrasi Kantor Dinas Kependudukan dan Catatan Sipil pada Kabupaten/Kota di Provinsi Kalimantan Selatan harus dapat lebih ditingkatkan, baik kemampuan memenuhi harapan, arahan, saran, sehingga akan menimbulkan kesadaran bahwa kinerja organisasi publik itu akan meningkatkan komitmen pada prinsip good governance dan clean governance dari para aparat birokraksi Dinas Kependudukan dan Catatan Sipil di Kabupaten/Kota di Provinsi Kalimantan Selatan, sehingga kinerja organisasi publik akan semakin sangat baik.

Secara umum kinerja pegawai di dinas tersebut lebih banyak termasuk dalam kategori baik yaitu $66,3 \%$, sedangkan yang menunjukan kategori kurang 33,7\%, dari total responden. Dari data tersebut hendaknya Dinas Kependudukan dan Catatan Sipil di Kabupaten/Kota di Provinsi Kalimantan Selatan dapat lebih meningkatkan kinerja pegawainya.

\section{Kualitas Pelayanan Publik}

Tanggapan pegawai di Dinas Kependudukan dan Catatan Sipil Kabupaten / Kota di Provinsi Kalimantan Selatan terhadap variabel kualitas pelayanan publik adalah sebai berikut. Pada indikator pertama, kualitas layanan publik diselenggarakan dengan prosedur atau tatacara yang mudah, cepat, tepat, tidak berbelit-belit, mudah dipahami, dan mudah dilaksanakan oleh masyarakat yang meminta pelayanan $70,4 \%$ pegawai menyatakan setuju. Indikator kedua, layanan publik yang berkualitas diselenggarakan dengan prosedur atau tatacara yang jelas dan pasti meliputi; persyratan pelayanan baik teknis maupun administratif, pejabatan yang berwenang dan bertanggung jawab dalam memberikan layanan, rincian biaya atau tarif pelayanan dan cara pembayarannya, serta jadwal dan waktu penyelesaian pelayanan $54,1 \%$ pegawai menyatakan setuju. Indikator ketiga, kegiatan layanan publik yang berkualitas dapat memberikan rasa aman, nyaman, dan kepastian hukum bagi masyarakat yang meminta pelayanan $78,85 \%$ menyatakan setuju. Indikator keempat, keterbukaan, layanan publik yang berkualitas diselenggarakan dengan prosedur atau tatacara yang transfaran atau terbuka dalam memberikan pelayanan kepada msyarakat terutama yang berkaitan dengan pejabat yang berwenang memberi pelayanan, waktu yang diperlukan menyelesaikan pelayanan, rincian biaya atau tarif pelayanan yang kesemunya itu wajib diinformasikan baik diminta maupun tidak diminta secara terbuka guna diketahui dan dipahami oleh masyarakat yang meminta pelayanan $57,1 \%$ menyatakan setuju tentang hal itu.

Pada indikator kelima, efisiensi, layanan publik yang diselenggarakan memenuhi kriteria efisiensi yang mengandung arti ; persyaratan pelayanan dibatasi pada hal-hal yang berkaitan langsung dengan pencapaian sasaran pelayanan, juga dicegah adanya pengulangan persyaratan dari satuan kerja / instansi pemerintah lainnya yang terkait $69,4 \%$ pegawai menyatakan setuju.

Tanggapan pegawai terhadap indikator keenam, layanan publik yang diselenggarakan memenuhi kriteria ekonomis yang mengandung arti; biaya pelayanan ditetapkan secara wajar dengan mempertimbangkan; nilai barang dan jasa pelayanan masyarakat, kondisi dan kemampuan masyarakat untuk membayar, serta sesuai dengan ketentuan peraturan perundangundangan yang berlaku sebagian besar $(65,3 \%)$ pegawai menyatakan setuju. Indikator ketujuh, layanan publik yang diselenggarakan memenuhi kriteria keadilan yang merata, yang mengandung 
arti; jangkauan pelayanan diberlakukan secara adil dan dengan distribusi yang merata ke segenap lapisan masyarakat sebagian besar pegawai (49\%) menyatakan setuju. Pada Indikator kedelapan, layanan publik yang diselenggarakan memenuhi kriteria ketapatan waktu yang mengandung arti bahwa; pelaksanaan pelayanan masyarakat diselesaikan dalam kurun waktu yang telah ditetapkan $66,3 \%$ pegawai menyatakan setuju. Sedangkan tanggapan pegawai pada indikator kesembilan, layanan publik yang diselenggarakan memenuhi kriteria kuantitatif, yang mengandung arti bahwa; kegiatan pelayanan publik dapat terukur kegiatannya yakni; adanya perbandingan jumlah pelayanan periode sebelumnya dengan periode berikutnya terdapat peningkatan, perbandingan antara waktu penyelesaian pelayanan dengan waktu pelayanan yang telah ditetapkan, penggunaan perangkat-perangkat modern untuk mempercepat atau mempermudah pelayanan masyarakat, serta menurunnya frekuensi keluhan terhadap pelayanan masyarakat yang diberikan $63,3 \%$ pegawai menyatakan setuju.

Indikator variabel kualitas pelayanan publik dengan nilai mean terbesar ialah variabel keadilan yang merata, hal ini tercermin pada kegiatan aparat birokrasi tentang layanan publik yang diselenggarakan mememnuhi kriteria keadilan yang merata, yang mengandung arti ; jangkauan pelayanan diberlakukan secara adil dan dengan distribusi yang merata ke segenap lapisan masyarakat pada kabupaten dan kota di Provinsi Kalimantan Selatan, yang kesemuanya itu mendorong kualitas layanan publik menjadi sangat baik.

Indikator variabel kualitas pelayanan publik dengan nilai mean terkecil ialah indikator kejelasan dan kepastian, yakni kegiatan kualitas layanan publik yang diselenggarakan dengan prosedur atau tata cara yang jelas dan pasti yang meliputi; persyaratan pelayanan, baik teknis maupun administratif, pejabat yang berwenang dan bertanggung jawab dalam memberikan layanan, rincian biaya atau tarif pelayanan dan cara pembayarannya, serta jadwal dan waktu penyelesaian pelayanan kepada masyarakat. Dengan demikian kejelasan dan kepastian dari para aparat birokrasi Kantor Dinas Kependudukan dan Catatan sipil pada
Kabupaten / Kota di Provinsi Kalimantan Selatan harus dapat lebih ditingkatkan, baik dalam hal kejelasan dan kepastian waktu penyelesaian, dan besarnya biaya pelayanan, sehingga akan menimbulkan kesadaran bahwa kualitas pelayanan publik itu akan meningkatkan komitmen pada prinsip good governance dan clean governance dari para aparat birokraksi Dinas Kependudukan dan Catatan Sipil di Kabupaten/ Kota di Provinsi Kalimantan Selatan, sehingga kualitas pelayanan publik akan semakin sangat baik.

Kualitas pelayanan secara umum di Dinas Kependudukan dan Catatan Sipil di Kabupaten/Kota di Provinsi Kalimantan Selatan paling banyak pegawai berada pada kategori baik $62,3 \%$, sedangkan pegawai yang termasuk kategori kurang baik 36,\&\%. Oleh Karena itu dinas tersebut perlu melakukan perbaikan terhadap kualitas pelayanan yang dimiliki oleh pegawainya.

\section{Pengujian Hipotesis}

Penelitian ini menemukan bahwa perilaku pegawai di kabupaten/ Kota di Provinsi Kalimantan Selatan yang merupakan suatu variabel dengan 4 indikator utamanya; Perilaku pegawai berpengaruh secara signifikan terhadap kinerja pegawai, juga berpengaruh secara signifikan terhadap kualitas pelayanan publik. Hal ini berarti dapat dibenarkan apabila 4 indikator tersebut yakni; indikator mengacu kepada kebutuhan dan kepentingan masyarakat (X1.2), indikator pemanfaatan sumber daya uang dimiliki (X1.3), indikator perioritas kebutuhan dan kepentingan masyarakat (X1.4), dan indikator kemampuan memberi solusi pelayanan (X1.5), yang kesemuanya itu merupakan cerminan dari konstruk Perilaku pegawai yang diterapkan oleh Pimpinan Kantor Dinas Kependudukan dan Catatan Sipil pada Kabupaten/Kota di Provinsi Kalimantan Selatan.

Penelitian ini juga menemukan bahwa kinerja pegawai di Kabupaten/Kota di Provinsi Kalimantan Selatan yang merupakan suatu variabel dengan 3 indikator utamanya; kinerja pegawai berpengaruh secara signifikan terhadap kualitas pelayanan publik. Hal ini berarti dapat dibenarkan apabila 3 indikator tersebut yakni; 
indikator responsivnes (X21), indikator responsibilitas (X2.2), dan akuntabilitas (X2.3), yang kesemuanya itu merupakan cerminan dari konstruk kinerja pegawai yang diterapkan oleh Pimpinan Kantor Dinas Kependudukan dan Catatan Sipil pada Kabupaten/Kota di Provinsi Kalimantan Selatan.

Penelitian ini menemukan bahwa kualitas pelayanan publik di kabupaten / Kota di Provinsi Kalimantan Selatan yang merupakan suatu variabel dengan 8 indikator utamanya; kualitas layanan publik berpengaruh secara signifikan terhadap kepuasan masyarakat. Hal ini berarti dapat dibenarkan apabila 8 indikator tersebut yakni ; indikator kesederhanaan (Y1), indikator kejelasan dan kepastian (Y2), indikator keamanan (Y3), indikator keterbukaan (Y4), indikator efisiensi (Y5), indikator ekonomis (Y6), indikator keadilan yang merata (Y7), dan indikator kuantitatif (Y9), yang kesemuanya itu merupakan cerminan dari konstruk kualitas layanan yang diterapkan oleh Pimpinan Kantor Dinas Kependudukan dan Catatan Sipil pada Kabupaten/Kota di Provinsi Kalimantan Selatan.

Hasil penelitian ini dapat dianggap sebagai dukungan prinsip pengembangan teori administrasi publik, khususnya Perilaku pegawai yang berkaitan dengan kinerja pegawai dan kualitas pelayanan publik. Hasil penelitian ini menemukan bahwa :

1. Perilaku Pegawai berpengaruh secara signifikan terhadap Kinerja pegawai dan juga berpengaruh secara signifikan terhadap Kualitas Pelayanan Publik pada Dinas Kependudukan dan Catatan Sipil di Provinsi Kalimantan Selatan, sehingga mendukung teori : Katz (1985), Frederick dalam Heady (1995), Tjokrowinoto (1992), Max Weber dalam Gibson et. al. (2013), Hicks dan Gullet (1996), Robbins (2006). Dengan demikian secara teoretis dinyatakan bahwa Perilaku pegawai penting pada proses pencapaian kinerja pegawai dan kualitas pelayanan publik dalam mendorong penciptaan kepuasan masyarakat.

2. Kinerja Pegawai berpengaruh secara signifikan terhadap Kualitas Pelayanan
Publik pada Dinas Kependudukan dan Catatan Sipil di Provinsi Kalimantan Selatan, sehingga mendukung teori :Cascio (1995), Wayne C. Parker (1996), J.S. Edralin (1997), LAN RI (2003), Lenvine dalam Dwiyanto (2009). Dengan demikian secara teoretis dinyatakan bahwa kinerja pegawai sangat penting pada proses pembentukan kualitas pelayanan publik dan penciptaan kepuasan masyarakat.

\section{KESIMPULAN}

Perilaku pegawai berpengaruh secara signifikan dan dengan arah positif terhadap kinerja pegawai Dinas Kependudukan dan Catatan Sipil pada Kabupaten/Kota di Provinsi Kalimantan Selatan. Berarti secara teoritis pengaruh perilaku pegawai terhadap kinerja ialah searah. Hal ini memberi makna, jika perilaku pegawai diterapkan pada Dinas Kependudukan dan Catatan Sipil Kabupaten/Kota di Provinsi Kalimantan Selatan semakin baik (positif), maka kinerja pegawai akan semakin tinggi. Sebaliknya, jika perilaku pegawai diterapkan pada Dinas Kependudukan dan Catatan Sipil Kabupaten/Kota di Provinsi Kalimantan Selatan kurang baik (negatif), maka kinerja pegawai semakin rendah.

Perilaku pegawai berpengaruh secara signifikan terhadap Kualitas Pelayanan Publik Dinas Kependudukan dan Catatan Sipil pada Kabupaten/Kota di Provinsi Kalimantan Selatan. Berarti secara teoritis pengaruh Perilaku pegawai terhadap kualitas pelayanan publik ialah searah. Hal ini memberi makna, jika Perilaku pegawai diterapkan pada Dinas Kependudukan dan Catatan Sipil Kabupaten/Kota di Provinsi Kalimantan Selatan semakin baik (positif), maka kualitas pelayanan publik akan semakin tinggi. Sebaliknya, jika Perilaku pegawai terhadap kualitas pelayanan publik diterapkan pada Dinas Kependudukan dan Catatan Sipil Kabupaten/Kota di Provinsi Kalimantan Selatan kurang baik (negatif), maka kualitas pelayanan publik semakin rendah.

Kinerja pegawai tidak berpengaruh secara signifikan terhadap Kualitas Pelayanan Publik 
Dinas Kependudukan dan Catatan Sipil pada Kabupaten/Kota di Provinsi Kalimantan Selatan. Hal ini memberi makna, jika kinerja pegawai diterapkan pada Dinas Kependudukan dan Catatan Sipil Kabupaten/Kota di Provinsi Kalimantan Selatan semakin baik (positif), maka kualitas pelayanan publik tidak sertamerta akan semakin tinggi. Sebaliknya, jika kinerja pegawai diterapkan pada Dinas Kependudukan dan Catatan Sipil Kabupaten/Kota di Provinsi Kalimantan Selatan kurang baik (negatif), maka kualitas pelayanan publik tidak sertamerta semakin rendah.

\section{REFERENSI}

Arikunto, Suharsimi, 2003, Prosedur Penelitian : Suatu Pendekatan Praktik, Edisi Revisi VI, Penerbit PT. Rineka Cipta, Jakarta.

Atep Adya Barata. 2003. Dasar-dasar Pelayanan Prima. Gramedia. Jakarta.

Bovaird, Tonny dan Elke Loffler (2003), Public Management and Governance, London: Routledge

Bungin, M., Burhan, 2013, Metodologi Penelitian Kuantitatif, Kencana Prenada media Group, Surabaya.

Bragan. 1992."Kinerja Birokrasi Pelayanan Publik".University Press, Yogyakarta.

Denhardt, Janet V and Robert B. Denhardt. 2000. The New Public Service : Serving, Not Streering. New York : M. E. Sharpe Inc

Djamaluddin, Arief. 2008. Pengembangan Sumber Daya Manusia dalam Persaingan Global. Jakarta: Pengembangan Bisnis dan Manajemen Global.

Dwiyanto, Agus 2009, Penilaian Kinerja Organisasi Pelayanan Publik, Yogyakarta : Fisip UGM.

Fahmi, Irham. 2016. Manajemen Sumber Daya Manusia Teori dan Aplikasi. Bandung: ALFABETA.

Gibbson, James, L., John, M. Ivancevich dan James H. Donnaly, 2013, Organisasi, Prilaku, Struktur dan Proses. Edisi 8, Terjemahan Bina Rupa Aksara, Jakarta.

Grindle, M.S., (editor), 1997, Getting Good Government : Capacity Building in the
Public Sector of Developing Countries, Boston, MA : Harvard Institute for International Development.

Hasibuan, Malayu, S. P. 2003. Manajemen Sumber Daya Manusia. Jakarta: Bumi Aksara.

Hicks \& Gullet, 1996, dalam Toyyibah Kundewi Yudiati (R. Ayu), 2005, Restrukturisasi menuju birokrasi publik yang efektif, Universitas Michigan, Penerbit Asli Mandiri, Jakarta.

Hughes, O. E., (2004), Public Management \& Administration, An Introduction, New York: The MacMillan Press. Ltd

Kaplan, R.S. dan David P. Norton. 2012, Balanced Scorecard Menerapkan Strategi Menjadi Aksi. Erlangga. Jakarta.

Lembaga Administrasi Negara. 2003. Penyusunan Standar Pelayanan Publik. LAN. Jakarta.

Marschall, Melissa J. 2004. Citizen Participation and the Neighborhood Context: A New Look at the Coproduction of Local Public Goods. Political Research Quarterly. Academic Research Library.

Nitisemito, Alex. 2011. Manajemen Personalia. Jakarta: Ghalia Indonesia.

Nurcholis, Hanif. 2005. Teori dan Praktik Pemerintahan dan Otonomi Daerah. PT. Grasindo. Jakarta

Osborne, David \& Plastrik. Peter. 2012. Memangkas Birokrasi. PPM. Jakarta. (terjemahan).

Rasyid, Muhammad Ryaas, 2000, Makna Pemerintahan - Tinjauan dari segi Etika dan Kepemimpinan, Jakarta : PT. Mutiara Sumber Widya.

Robbins, Stephen P. 2006. Perilaku Organisasi. Jakarta: Kelompok Gramedia.

Siagian, Sondang P. 2013. Administrasi Pembangunan. Jakarta: Bumi Aksara.

Sinambela, Lijan P. 2016. Manajemen Sumber Daya Manusia; Membangun Tim Kerja yang Solid untuk Meningkatkan Kinerja. Jakarta: Bumi Aksara.

Tjiptono, Fandy, 2014, Prinsip-Prinsip Total Quality Service, Penerbit Andi, Yogyakarta. 
Thoha, Miftah, 2012, Perilaku Organisasi

Jakarta.: Rajawali Pers.

Tohardi, Ahmad. 2002. Pemahaman Praktis Manajemen Sumber Daya Manusia. Bandung: Mandar Maju

Wahab, Abdul, Solichin (2004), Analisis Kebijaksanaan dari Formulasi ke Implementasi Kebijakan Negara, Bumi Aksara, Jakarta. 